Florida International University

FIU Digital Commons

FIU Electronic Theses and Dissertations

University Graduate School

3-26-2020

\title{
Nigeria's Membership in the Organization of Islamic Cooperation: Origin, Nature, and Impact
}

\author{
Eddy Aitah \\ Eaita001@fiu.edu
}

Follow this and additional works at: https://digitalcommons.fiu.edu/etd

Part of the Africana Studies Commons, African Languages and Societies Commons, Islamic Studies Commons, and the Religion Law Commons

\section{Recommended Citation}

Aitah, Eddy, "Nigeria's Membership in the Organization of Islamic Cooperation: Origin, Nature, and Impact" (2020). FIU Electronic Theses and Dissertations. 4375.

https://digitalcommons.fiu.edu/etd/4375

This work is brought to you for free and open access by the University Graduate School at FIU Digital Commons. It has been accepted for inclusion in FIU Electronic Theses and Dissertations by an authorized administrator of FIU Digital Commons. For more information, please contact dcc@fiu.edu. 


\title{
FLORIDA INTERNATIONAL UNIVERSITY
}

\author{
Miami, Florida
}

NIGERIA'S MEMBERSHIP IN THE ORGANIZATION OF ISLAMIC COOPERATION: ORIGIN, NATURE, AND IMPACT

\author{
A thesis submitted in partial fulfillment of the \\ requirement for the degree of \\ MASTER OF ARTS \\ In \\ RELIGIOUS STUDIES
}

by

Eddy Aitah 
To: Dean John F. Stack, Jr.

Green School of International and Public Affairs

This thesis, written by Eddy Aitah, and entitled, Nigeria's Membership in the Organization of Islamic Cooperation: Origin, Nature, and Impact, having been approved in respect to style and intellectual content, is referred to you for judgment.

We have read this thesis and recommend that it be approved.

\begin{tabular}{r} 
Albert Wuaku \\
Tudor Parfitt \\
\\
\hline Iqbal Akhtar, Major \\
Professor
\end{tabular}

Date of Defense: March 26, 2020

The thesis of Eddy Aitah is approved.

Dean John F. Stack, Jr

Green School of International and Public Affairs

Andrés G. Gil

Vice President for Research and Economic Development and Dean of the University Graduate School

Florida International University, 2020 


\begin{abstract}
OF THE THESIS
NIGERIA'S MEMBERSHIP IN THE ORGANIZATION OF ISLAMIC COOPERATION: ORIGIN, NATURE AND IMPACT
\end{abstract}

by

Eddy Aitah

Florida International University, 2020

Miami, Florida

Professor Iqbal Akhtar, Major Professor

This thesis explores Nigeria's membership into the Organization of Islamic Cooperation (OIC), covertly instituted by General Ibrahim Babangida who rose to power as Nigeria's military head of state in 1985, a strategic move that resulted in socioeconomic benefits which improved the standard of living of the people of Nigeria. Regionally divided, Muslim influence on the north, and Christian to the south. The commingling with other traditional Nigerian religious cultures, sociopolitical strategies and legislative protocol are contested by these opposing factions on a continuum. Using archival research methods, both textual and multimedia, this work posits that despite the religious controversies and dichotomies that encompass the presence of the OIC in Nigeria's socio-religious, political, and economic milieu, Nigeria has historically benefited and continues to profit from various extensions of the OIC, such as the Islamic Development Bank (IDB), the Islamic Educational, Scientific, and Cultural Organization (ISESCO), and the Standing Committee for Economic and Financial Cooperation (COMCEC). My research expounds on the arguments against popular notions and 
debates of Islamization, or the process of shifting a society's sociocultural perspectives to Islam, a notion upheld by Christians with Babangida's ascendance to power. 
CHAPTER

PAGE

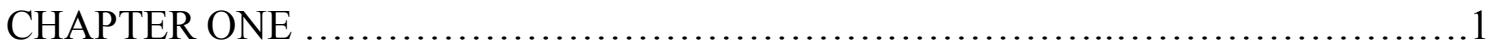

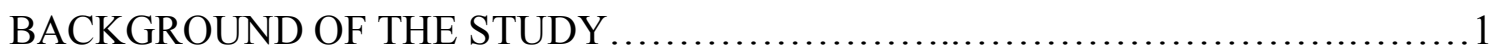

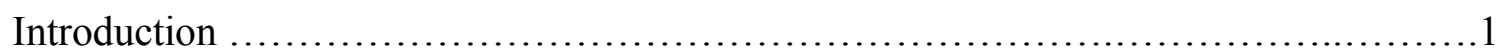

Statement of the Problem......................................................

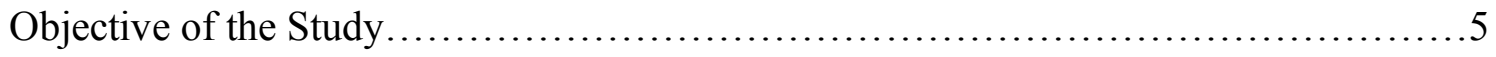

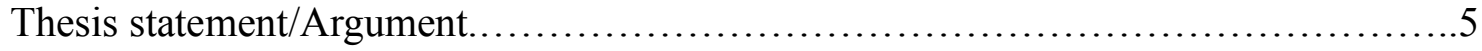

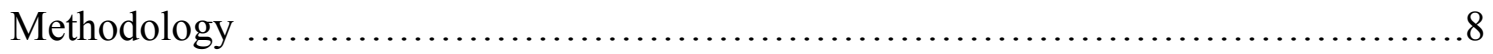

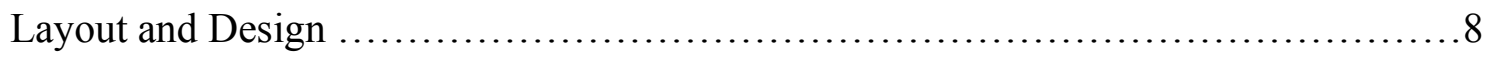

CHAPTER TWO ........................................................

THEORETICAL CONCEPTS AND RELEVANT LITERATURE ................... 10

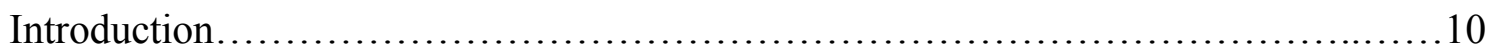

Relevant Theoretical Concept...............................................10

Review of Relevant Literature...........................................13

CHAPTER THREE........................................................ 27

THE ORGANIZATION OF ISLAMIC COOPERATION: EVOLUTION AND

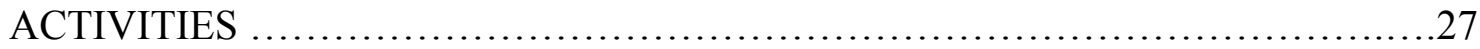

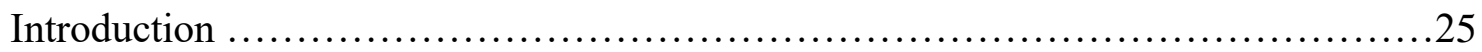

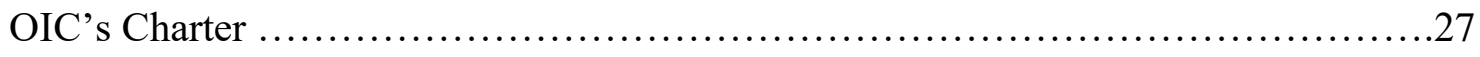

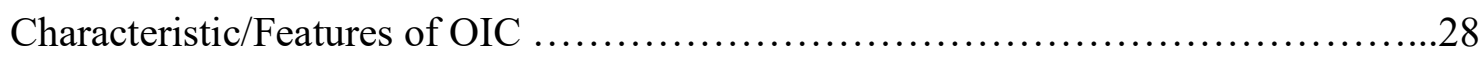

Structures and Specialized Organs .......................................29 
CHAPTER FOUR

NIGERIA'S MEMBERSHIP IN THE IOC: CHALLENGES AND

BENEFITS

Introduction .37

Rationale/Factors that Necessitated Nigeria's Membership in the IOC .37

Major Challenges (Criticisms) of Nigeria's Membership in the IOC

Nigeria's Membership in the IOC: Critical Analysis

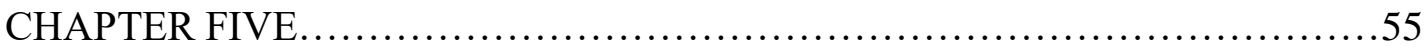

CONCLUSION .55

Recommendation. .57

Bibliography .58 


\section{CHAPTER ONE}

\section{BACKGROUND OF THE STUDY}

Growing up in Nigeria, most Christians I have interacted with always demonstrate their fear of an Islamic takeover in the country, especially when it comes to presidency and the Nation's leadership. In 2015 during the Presidential Election in Nigeria between Goodluck Jonathan and Muhammadu Buhari, there was propaganda within the Christian community that should Buhari become president, the Nation would lose its secularity and become an Islamic state. I vividly remember when my mom, who could not attend the voting site herself, fervently warned me against voting for Buhari. When Buhari was announced President, she wept genuine tears of fear. This is a prime example of the same fear which embodied Christians during Nigeria's membership in the Organization of Islamic Cooperation.

The Organization of Islamic Cooperation (OIC) is an international organization consisting of fifty-seven member states which are mostly populated by Muslims. This organization is a collective voice for the Muslim community, and it aims to safeguard and

protect the interests of the global Islamic community (ummah). To promote international peace and harmony, the Islamic States, since 1924, have tried to bring the Islamic world into a single international organization (Al-Gabid, 1993; Adam, 2015; Akeel, 2012). Several events laid the foundation of its final constitution, namely:

a. The Third Islamic Conference held in 1931 in Jerusalem, which hosted many Muslim intellectuals. 
b. The first conference of Muslim political leaders held in August 1954, in which a bill approving the consolidation of the establishment of the OIC was passed.

c. The Islamic Summit Conference of 1969 held in Rabat, which discussed the problems and interests of the Muslim community (Al-Gabid, 1993).

d. The 1969 Summit held in Rabat, where the OIC was finally founded (Akeel, 2012).

In 1970, between March 23rd and 25th, King Faisal of Saudi Arabia convened in Jeddah the First Islamic Conference of Foreign Ministers. Those in attendance were mutually seeking international cooperation and the creation of a forum on significant issues that affect the Muslim world (Adam, 2015). March 1972, during the Third Islamic Conference of Foreign Ministers, held at Jeddah, the charter of the OIC was approved and adopted, giving rise to a new organization that put particular emphasis on the notion of Islamic solidarity (Ihsanoglu, 2010; Akeel, 2012; Hassan, 2015).

The organization is open to all Muslim states and other states which have a significant Muslim population, irrespective of their geographical locations. The Palestine Liberation Organisation (Palestine), along with thirty other current members are founders. The organization also grants "observer" status to entities (such as the Moro Islamic Liberation Front of the Philippines and the Turkish Cypriot Muslim community), other international bodies (such as the African Union or the Arab League), and even states like Russia (Akeel, 2012). 
When Ibrahim Babangida assumed office, his emphasis on the secular nature of the constitution and its application seemed to allay the fear of Islamic imposition on other members of society (Kukah, 1993). Unfortunately, the calm was short-lived. Ibrahim Babangida led the military government of Nigeria to enroll as a member of the OIC on February 3, 1986. This government's act of forcing Nigeria, which is a constitutionally secular state, into the OIC, prompted resistance from members of the Christian faith and created political unrest. The Nigerian government's action intensified religious divisions throughout the country. Christians, in opposition, demanded Nigeria to withdraw immediately, the Muslims, in support, argued that the country's secular posture was not affected by its membership.

Despite the tension created by the OIC, Nigeria became the 46th member of the OIC and is a member to this date. This scenario shows that despite the potency of public opinion in foreign policymaking, ultimately, decision-making on foreign policy in Nigeria remained in the hands of the Ministry of Foreign Affairs and the president. Changes, however, have taken effect, and the president now has an ultimate say and can even isolate the Ministry of Foreign Affairs in the implementation of specific policy options.

On June 4, 2019, members of some human rights organizations protested the incumbent president Muhammadu Buhari's participation in an OIC Summit, held in Mecca, Saudi Arabia during the OIC's 50th anniversary (Premium Times, 2019). Their argument was based on the fact that Nigeria is multi-religious and secular by its constitution. The criticism and counter criticism over Nigeria's enrollment into the OIC and the country's ongoing support would increase tension and disrupt progress. This 
study analyzes the impacts and benefits that have occurred since 1986 when Nigeria joined the OIC and shows that the move was not to institute Islam as the religion for the entire country.

Statement of the Problem

In 1986 when Nigeria became a full member of the OIC, there was a series of countrywide debates. The Muslims who were pro-OIC believed that Christians were overreacting by kicking against the foreign policy. Additionally, they argued that since countries like Rwanda, Gabon, Cameroun, Sierra Leone, Uganda, Kenya, and the Benin Republic, whose heads of state were Christians, were already members of the OIC, there was no need for backlash (Adam, 2015; Jama'atu, 1986). They also emphasized that there were more positive benefits than negative impacts of being a member of the OIC. The anti-OIC constentiuents; however, argued that the African countries that have enrolled in the organization were troubled nations seeking urgent assistance to resolve their crisis. They also argued that OIC membership would not yield Nigeria any economic benefit, that Nigeria would be subject to a financial burden due to its size and abundant resources (Falola, 1998).

This foreign policy decision, as implemented by Babangida's administration in 1986, during the post-independence era, initiated remarkable strain between Muslims and Christians (Lukur, 1999). Religious riots between the two sides were witnessed, especially in the Northern region. Despite these demonstrations, Christians were not reacting as vehemently during this time (Lukur, 1999). Lectures, seminars, and books were written to generate an order. Though Nigeria only had observer status in the OIC, many Christians doubted the credibility of the military dictatorship of Babangida (Kukah 
\& Falola, 1996). Decree No. 26 by the Babangida administration, promulgated on November 25, 1986, under the platform of constitutional amendments, aided with the imposing of the Sharia (Kukah \& Falola, 1996). The Sharia can be defined as "the clear, well-trodden path to water." Sharia law acts as a code for living that all Muslims should adhere to, including prayers, fasting, and donations to the poor. It aims to help Muslims understand how they should lead every aspect of their lives according to God's wishes. The word "personal" (limiting the application of the Sharia to the sphere of family law and practice) was deleted wherever it occurred after the word "Islamic" (which extended the scope of the application of the Sharia with its collateral consequences) in the Nigerian Constitution (Iarzan, 1992). Sections 217,223(1), 226 (a), 241(3) and 242, provided the Sharia with a wide range of civil application, and possible 'universalization' (prosecution of non-Muslims according to Islamic law) in the context of the Nigerian legal code (Nwanaju, 2005).

Nigeria, a multi-ethnic, densely populated, country has dominating religious practice of Christianity, followed by Islam. Speculation arose as to why the foreign policy option was processed without consultation to or support from Nigeria's citizens.

\section{Objectives of the Study}

The study seeks to examine the origin, nature, and impact of Nigeria's membership of the OIC and matters arising from this policy option. The specific objectives of this study are:

1. To examine the OIC's historical development

2. To analyze the OIC's role 
3. To investigate the nature of Nigeria's membership in the OIC; and

4. To compare and contrast the challenges and benefits of Nigeria's membership if the OIC.

Thesis Statement

This study examines the origin, nature, and impacts of Nigeria's membership in the OIC. It argues that Nigeria's enrollment into the OIC in 1986, by the General Ibrahim Babangida's administration, was to create international religious solidarity for the Muslim population in the country and simultaneously acquire economic benefits to the country. The Nigerian government perceived that the OIC, through its specialized and affiliated institutions, (e.g., the Islamic Development Bank (IDB), the Islamic Educational, Scientific and Cultural Organization (ISESCO), Standing Committee for Economic and Financial Cooperation (COMCEO), and others), would provide an advantageous activity for the country.

Before Nigeria's full membership, the Islamic organization had a record of assisting member-states, in the development and implementation of agricultural, educational, and health-related projects. This observation, as well as other instances, were made while Nigeria was partially enrolled and held the status of an "observing member" (Olukoshi, 1990). The Islamic Organization was notorious for having a tangible economic impact on some of its member states. Not only did the OIC provide financial support, but it provided food to locations experiencing famine (Olukoshi, 1990). The decision to convert to an active member began in 2005 when President Olusegun Obasanjo enrolled Nigeria into the Islamic Development Bank by obtaining 0.03 percent of the overall bank's capital (Ezeanokwasa, 2007). 
Despite the long-term benefits of Nigeria's enrollment to the OIC, the immediate outcome was a national crisis and division between the adherents of the two major religions in the country, Christians and Muslims. Christian leaders organized protests demanding the government to withdraw its membership immediately (Kukah, 1993). Christian journalists criticized the administration of General Badamosi Babangida, stating that Nigeria's secular status should prohibit involvement with organizations exclusive to a specific religious party. Although the Charter of the OIC indicates that the president and foreign minister of a member nation must be a Muslim, a concern was that since the OIC is an intergovernmental religious organization of all Muslim nations, it would unofficially imply that Nigeria was a Muslim nation. Another fundamental concern was the potential loss of religious freedom, which could occur from the country's economic rights to the Islamic community. Even though economic development was one of the alleged reasons for enrolling Nigeria into the OIC, it appeared that the government had been too reserved with the ongoing issues.

Muslim leaders welcomed the decision to enroll Nigeria into the OIC. They argued that Christians exaggerated the negative implications of the OIC membership, pointing out that countries with Christian heads of state like Rwanda, Gabon, Kenya, Uganda, Sierra Leone, Cameroon, and the Benin Republic, were members of the OIC yet not religious, similar to the United Nations (Lawal, 2018).

Considering all arguments, this thesis validates and supports that Nigeria's membership in the OIC did bring immense economic benefits to the country, thus fulfilling the primary reason for its involvement. In support of this view, the study will examine the structure, nature, and roles of the OIC, and review the challenges and 
benefits of Nigeria's membership in the organization. The study's scope is limited to the evolution and ideology of the OIC, factors that necessitated Nigeria's admission into the OIC, and the benefits Nigeria has gleaned from being a member of the organization.

This thesis will point out the significant reasons that international organizations like the OIC influenced the foreign policy posture of African countries. There will be a particular reference to Nigeria to clarify the enrollment of Nigeria into the OIC as a foreign policy objective, which is at the sphere of the Federal Government and the Ministry of Foreign Affairs. Additionally, this study will highlight the economic benefits Nigeria has gained from its membership in the OIC in comparison to how it has Islamized the country.

\section{Methodology}

The researcher employed both the primary and secondary methods of data collection. That is, the researcher, collated and analyzed both primary and secondary materials. Primary data was sourced from official gazettes and information obtained from personal interactions with experienced professionals in the field of International Studies and Diplomacy. Additional primary data was sourced from personal experience gained during my undergraduate studies in Religious Studies as well as testimonies of some Christian and Muslim clerics during our interactions. Secondary data sources include textbooks, journal articles, newspapers, magazine publications, and internet materials. These will provide supplemental support to information obtained from the primary source. 
The primary information will be reviewed with the secondary materials to triangulate the research and reach a logical conclusion on the subject matter of this study.

Layout and Design

The study is being structured into five chapters, as follows:

\section{Chapter One: Introduction}

This chapter presented the introduction of the research. It provided a brief background analysis of the evolution of the Organization of Islamic Cooperation, incidences that led to its creation, and the nature of Nigeria's enrollment into the organization

\section{Chapter Two: Theoretical Concepts and Relevant Literature}

This chapter provides a theoretical base and conceptual review of religion, international organizations, and the position of religion in international relations among states in the global system.

Chapter Three: The Organization of Islamic Cooperation: Evolution and Activities This chapter presents a historical analysis of the evolution and activities of the Organization of Islamic Cooperation as an international organization. The chapter focuses specifically on the organization's charter, its characteristics/features, its main structures/organs, and its major functions. 
Chapter Four: Nigeria's Membership in the Organization of Islamic Cooperation:

\section{Challenges and Benefits}

This chapter presents an analytical explanation of the reasons and nature of Nigeria's

membership in the OIC, the major benefits that accrue to the country, and the challenges of being a member of the Islamic organization while being a secular state.

Chapter Five: Conclusion

This chapter concludes the study. It provides a summary of the various points presented, makes some suggestions as to how Nigeria can improve its socio-economic status through its membership in the organization while ensuring peaceful coexistence among the various religious groups in the country. 


\section{CHAPTER TWO}

\section{THEORETICAL CONCEPTS AND RELEVANT LITERATURE}

In the study of religion, different theoretical concepts shape inter-relationships in the global system. Theories used for this study include Pierre Bourdieu's Theories of Habitus and Fields, which assisted in explaining how individuals act within society. According to the Oxford Dictionary, "Religion is the belief in and worship of a superhuman controlling power, especially a personal God or gods." Many people view religion as a faith-based reward; it satisfies an individual's mode of worship, gives freedom of association, and permits room for interaction with others of the same faith. As people worship in groups, they interact and conform to the common doctrine. The adopted doctrine becomes part of their way of life, thus determining the nature of their societal and global association.

Pierre Bourdieu's Theory of Habitus

Pierre Bourdieu postulated the theory of Habitus in 1977. In Bourdieu's words, habitus can be defined as:

"structured structures predisposed to function as structuring structures that are as principles which generate and organize practices and representations that can be objectively adapted to their outcomes without presupposing a conscious aiming at ends or an express mastery of the operations necessary to attain them" (Bourdieu, 1990: 53).

The term 'is derived from Latin to mean 'habitual.' Although its underlying theoretical basis was influenced by the works of Political Theorists like Aristotle, Weber, Hegel, Durkheim, and others, the actual definition and utility of the theoretical concept of habitus were created by Pierre Bourdieu in the 1970s. 
"Habitus" is made up of tools like morals, myths, beliefs, etc. that have been employed in the shaping of our thoughts, behaviors, attitudes, and our general outlook on life. Over time such actions and behaviors revolve around these adapted patterns. Human beings encounter experiences in their everyday life, which may influence their decision making and the thought processes of their future actions.

The theory of habitus and the fear of Islamization are what propelled Christians to revolt against Nigeria's involvement in the OIC because of fear of social norms being adapted to Muslim practices such as the Sharia law, which enforces heinous punishment for actions which are considered as a sin. Other practices such as underage marriage would affect the overall outlook on life, especially for children who experience it personally. There are also the colonial and post-colonial experiences in their various forms, and it is evident that these experiences have impacted African's mentality and self-image. (Wacquant, 2005).

Habitus is, therefore, part of the socialization process where everything that we experience is understood and categorized according to past experiences. Events that occur during childhood are particularly important in developing a "matrix of perceptions" that affect how people view the world and, more importantly, how they react in different contexts (Jones, 1997; Swartz, 1997).

Theory of Fields:

Another theoretical concept that is important in analyzing Nigeria's membership in an Islamic organization is the idea of "fields." This consists of various social and institutional arenas in which people express and reproduce their dispositions and compete for the distribution of different kinds of capital (Gaventa 2003). A field is a network, 
structure, or set of relationships which may be intellectual, religious, educational, cultural, etc. (Navarro, 2006). People often experience power differently, depending on which field they are in at a given moment (Gaventa, 2003). Context and environment are vital influences on habitus.

Bourdieu (1990) accounted for the tensions and contradictions that arise when people encounter and are challenged by different contexts. His theory can be used to explain how people can resist power and domination in one field yet express complicity in another (Moncrieffe, 2006)

Fields help to explain the belief system (religions) in individuals and the state's decision making. Nigeria's membership in the OIC emanates from the desires of the Nigerian political elites (Muslim leaders) to promote global Muslim solidarity.

Situating these theoretical concepts to this study, especially Nigeria's socialization with the global world, the activities of the missionaries, and the jihad during the pre-colonial era, religion has since become a major decider in interactions with the global system. For instance, Nigeria's membership in the OIC, a religious organization, was partly due to the desire of the political leaders to socialize with and annex the numerous benefits, especially as it affects the Muslim population in the country and attracts support that may accrue from such relations. This study focused on four major fields: political, religious, economic, and capital. This thesis depicts the debate between how the political field tried to claim hegemony over the religious field. Babaginda, demonstrated this when he led the government and used his political power to introduce the country into the OIC, which is a religious field, according to Bourdieu. This thesis also brings light to how all the fields interact. Nigeria 's membership in the OIC reaps 
benefits from the economic field however the political field also reaps benefit from the capital field. The religious field played a positive influence on the people who were supporters of membership in the OIC. These pro-OIC people are assets in the capital field for those in the political field seeking position and advocacy. When Nigeria began to reap economic assistance and development from the OIC, and as more Nigerian civilians changed their views on the Nigeria's membership in the OIC, the economic field further impacted and expanded the capital field. As the capital field expanded, the political field's assets also grew in numbers. In this study, although the OIC's core field is the religious field, being it an organization which stems from religious roots, the positive impact of the OIC in Nigeria is mainly demonstrated in the economic fields.

\section{Review of Relevant Literature}

According to the Merriam-Webster dictionary, Religion is a social-cultural system of designated behaviors and practices, morals, worldviews, texts, sanctified places, prophecies, ethics, or organizations that relate humanity to supernatural, transcendental, or spiritual elements. Considering that religion deals with behaviors and personal morals, some argue that it should not be factored into the operations of international organizations or linked with such tools like trade, economy, culture, politics, and environmental issues. Having realized the imperative sensitivity towards local value systems, promoting developmental efforts, and the protection of religious freedom and interactions, religious organizations like the OIC, are progressively influencing policymaking. 
Many studies indicated that international organizations perform useful functions in the international system. They offer provision for cooperation in areas in which cooperation is advantageous for any of their member states. They also provide multiple channels of communication between states. They offer multiple and continued points of contact and is essential when support is needed in times of conflict. The increase of global divisions and conflict has provided some with the justification for arguing that the growing trend of international organizations has also increased diversity centered issues.

The OIC, like other organizations, holds significance to many countries, including those whose constitution is secular, are not an Islamic state, yet have a large Muslim population. OIC gives ear to matters affecting the Muslim community, including pilgrim's matters in Saudi Arabia. The need for diversity support is just one of the many relevant magnetic attractions in which countries like Nigeria were susceptible to when seeking membership.

This section of the research presents a conceptual review of the applicable literature used in the study. It is important to understand the key terms: Religion, International Organization, and the challenges and prospects of Religion in International Relations among states in the global system.

\section{Concept of Religion}

Conceptualizing religion is indeed problematic as scholars from various perspectives have different perceptions of the term. Therefore, Beckford (2003) opined that 'it is conceptually problematic to come up with a single universal definition of religion' as it is almost as old as time itself, and its many dimensions change as the everconstant nature of change" (p.197). Mapadimeng (2009) states, "there are clear-cut 
disagreements on the subject-matter at the definitional level” (p.142). Haralambos and Holborn (2008) outlined two groupings of definitions to include functional and substantive approaches. According to Talcott Parsons (1952), a religion based on its perceived functional traits should be defined as

“...a set of beliefs, practices, and institutions which men have evolved in various societies, so far as they can be understood, as responses to those aspects of their life and situations which are believed not in the empiricalinstrumental sense to be rationally understandable and controllable, and to which they attach a significance which includes some reference to a supernatural order" (Parsons, 1952, p.464).

This, however, differed from the opinions of more context-bound social theorists such as Mapadimeng (2009), who asserted that it is unhelpful for religion to be viewed as homogenous, simple, a unitary practice, or phenomenon, and as such aligned his research with Beckford (2003). Beckford conceived of it to be "a social construct founded in and informed by specific socio-political and historical context giving it diverse and dynamic unfixed meanings" (p.14). A focus on the content of religion as well as its structures using which it perpetuates itself supports the definitions of Spiro (1966). Spiro conceived of religion as "an institution consisting of culturally patterned interactions with culturally postulated superhuman beings" (p.96-97). Bruce (2003) defined it as "beliefs, actions, and institutions that assume the existence of supernatural entities with powers of judgment and action" (p.14). Thus from the above different definitions of religion, one can conclude that it is: (i) a set of beliefs, actions, and institutions which (ii) arise out of social interactions that (iii) assumes the existence of the sacred and the profane, and (iv) 
performs the role of giving members of its society a social identity, norms by which to live, and sanctions for their failings.

Obilor (2002), defined religion as, "the whole complexes of attitudes, conviction, and institutions through which we express our deep fundamental relationship with reality and not excluding the created order" (p. 63). Gilbert (1980), stated that "religion describes any system of values, norms, and related symbols and rituals, arising from an attempt by individuals and social groups to affect certain ends, whether in this world or any future world by means wholly or partly supernatural" (p.5). The transcendental perspective of religion is aptly captured in the definition of Odumuyiwa (2006). He defined religion as "man's effective desire to be in right relationship with a sacred transcendental order, controlling human destiny and events, either a prescribed system of rituals or belief" (p.2). Omoregbe (1993) defined religion as essentially a relationship, "a link established by the human person and the divine person believed to exist" (p.3).

Odumuyiwa (2006), also stated that religion is the recognition of all our duties as divine commands (p.2). It can be deduced from the definitions above that religion coveys the following: features of a supernatural being, the belief in that being, and a feeling of awe and mystery in response to the command of that supernatural being. The writer, therefore, defined religion as our "absolute acknowledgment of dependence on the supernatural being who sets and controls the entire affairs of life and the universe, hence attracting our reverence and obedience" (p.2).

This dimension may have been responsible for the emotional power that religion has on the adherents. This is exemplified in the actions of some religious adherents who often feel that their actions are for God, whereas these activities may be against God. 
Things such as to maim, kill, destroy, and loot are bracketed under activities for God. However, these activities are against the rules or laws that society creates. Others argue that actions which are harmful to society cannot possibly be beneficial for God. Hence religion, which stems from beliefs, may have a profound impact on society. This impact extends in all aspects, politics, law, education, culture, behavior, festivals, and more.

Religion performs numerous functions in human society. It provides a pattern of social identification, creates a collective bond, and a sense of belongingness that may exist outside the family unit of individuals within the society. Religion acts as a source of unification of different persons from different social, cultural, and political backgrounds. Social control is maintained by the repetition of actions utilizing which the religion perpetuates those aspects that it declares as sacred, denounces those it considers otherwise as profane. Members who fail to abstain from the behaviors prohibited by the group, not only lose their sense of identity but suffer psychologically (McCullogh \& Willoughby, 2009) as well as experience social holds. Members at risk of being at the receiving end of the punitive measures to be meted out by the supernatural, who are assumed to be custodians of the sacred.

According to Bruce (2003), religion plays a dual function in human society. On the one hand, it could foster social cohesion by binding people together under a collective reality, which is socially constructed and termed 'God' or 'cosmology' or 'morality.' On the other hand, could promote change and disruption to the existing socio-political order, as can be noted in the 19th century Uthman Dan Fodio-led Jihad and with the current activities in Nigeria with the religious extremist Boko Haram. 
Beckford (2003) argued that "the role of religion given that it was a socially constructed reality, would not be singular or simple, but rather complex and varied depending on the ends it sets out to achieve" (p.28). Religion's role in social change could, according to Bruce (2003), could be enhanced if religious radicals used their influence to create a positive change.

\section{International Organizations}

According to Armstrong, D. Lorna L. and John R. (2004), an international organization has been defined "as a form of co-operation of sovereign states based on multilateral international organizations and comprising of a relatively stable range of participants. The fundamental feature of which is the existence of permanent organs, with definite competences and powers acting for the carrying out of common aims" (p.12). International organizations can also be defined as "a process of organizing the growing complexity of international relations. They are the institutions that represent the phase of that process. They are also the expressions of and contributors to the process, as well as the significant factors in contemporary world affairs" (McCormick, 1999:6).

Akinboye and Ferdinand (2009) defined the term international organization as a global organization that accommodates the world community. Pearson and Rochster (1984), defined global organizations as "inter-governmental organizations in global terms, draw their members from every region in the world.

According to Hughes (1994), universal or international organizations:

draw members from around the world. The United Nations is essentially universal, although some of these institutions fail to represent some parts of the world (Hughes, 1994, p.260). 
In the view of Ray (1992), international organizations are: "organizations with a wider scope, primarily the United Nations and related organizations, whose membership is open to all states and whose ostensible goal is to serve the interests of the entire community of states" (p. 425).

Palmer and Perkins (1969), perceived international organizations as "any cooperative arrangement instituted among states by agreement, to perform mutually advantageous functions implemented through periodic meetings and staff activities" (p.299). This definition implies that international organizations could be an international public service institution, which is a distinctively modern aspect of world politics. For Duverger (1972), an international organization is seen as the process of organizing international relations. The scholar states that:

it represents a form of international institution which is a formal system of rules and objectives, a rationalized administrative instrument that is technically and materially organized with its constitution, local chapters, physical equipment, machines emblems, letterheads, stationery, a staff, an administrative hierarchy, and so on" (p. 68).

This definition shows clearly that "an international institution has a wider applicable and encompasses the notion of a system of relations which do not necessarily manifest themselves as regularized international relations, as is the case in international organizations with formal and material existence" (Archer, 1992, p.4).

International organizations can be classified according to three characteristics; membership aims, functions, and structures. An organization may be universal, regional, or pluralistic. Apart from the OIC, other examples of international organizations are The 
United Nations (UN), The International Monetary Fund (IMF), the International Labor Organization (ILO).

In recent years, religious NGOs have been very active through instruments of influence such as information politics, symbolic politics, leverage politics, responsibility politics, and global movement networks. NGOs mobilize public opinion, social elites, and foreign policymakers to achieve their policy goals. Together with the western "small or middle powers" or "good Samaritan states" that respect the global social democratic values and policies, it is becoming an important factor in promoting global governance and provide public goods outside of the international system led by big powers (Lami, 2011, pp. 244-254).

As a new international influencer, religious NGOs represent a "power transfer" in current international relations. Although religious NGOs do not have the traditional legitimacy resources enjoyed by the nation-states, they can resort to economic sanctions and other means of "'humanitarian intervention'" to achieve their goals (Jarvik, 2007, p. 217). Though the so-called "humanitarian fundamentalist" approach of justifying the means by the end, these organizations play the religiously positive function in international relations by breaking down the boundaries of region, race, color, and culture, as well as promoting economic empowerment, social improvement, cognitive liberation, political democracy, freedom of belief, multinational rescue missions, international exchanges, global governance, and world peace. Thus, various religious actors not only play a vital role in the current international arena, but they also quietly contribute to numerous concrete areas of international governance. 


\section{Implications of Religion in International Relations}

Religion plays several roles in the human society, including the allocation of both spiritual and physical values, interpretation of values through the divine or written scriptures, and a major guide in the nature or pattern of decision making of both individuals in the society and states in the global system. Religion also emphasizes universality's borderless nature and the need for cooperation between and among entities in the global system. Likewise, international relations are system that attempts to allocate and define international values through state interests, political power, and moral legitimacy.

Core texts from the late 1990s, such as Hans Morgenthau's Politics Among Nations and Kenneth Waltz's Theory of International Politics, provided nothing momentous to understand the function of religion in politics. Instead, both texts encouraged their readers to lessen their consideration of religion and focus little on the concept. A major explanatory tool for international relations was the concept of power and how it was distributed among states (Toft, 2010). Power was seen as the focal point in the decision making of states. When religious ideas entered the fray, they were viewed as instrumental means employed by statesmen, either to gain power or to eliminate political enemies (Toft, 2010).

The former position of the 90 s has changed, and current scholars of international relations such as Toft (2010) believe that religion has resurged globally in political influence. It is said that this turn of events is supported by the forces of democracy, globalization, and technology, which were supposed to eliminate it (Duffy, 2011). Another factor is that, despite Western scholars claiming that religion is exclusively 
irrational and violent, its political influence in fostering democracy, reconciliation, and peace.

Although religion may give humankind a unified identity, regardless of their race, it is also responsible for many of the world's conflicts. Organizations like the OIC govern their existence on their religious views; hence the majority of the members are states which share their same values.

The deployment of religion as a basic factor in foreign policy decision making, concerning Nigeria's membership in the OIC in 1986, generated a lot of challenges and reactions. According to Kukah (1993), "there has been evidence of international Islamic connection through the excessive flow of financial support over the years for the propagation of Islam in northern Nigeria" (p.42). Again, the Sharia debate in the Constitutional Assembly of 1988, and its subsequent adoption in the year 2000 in some states in the north, took place with total disregard for the constitutional provision of the secularity of the Nigerian state, which separates religion from state affairs. Similarly, Nigeria's membership in the OIC made many Nigerians question the secularity of the Federal Republic of Nigeria. The pilgrimage ceiling of 20,000 Muslims and 1,300 Christians by the Buhari administration in the 80 s, was also seen as another threat to nonIslamic religions (Usman, 1987). These experiences have made people edgy about religious issues. The resulting volatility led to frequent crisis destroying the nation's peace, human rights, and good governance. Africa as a whole is witnessing a human tragedy in the Central African Republic, where citizens of one religious denomination are destroying citizens of other religious faiths (Human Rights Watch, 2014). 
One can deduce that Arab nations' constant grant to promote the Islamic religion, as well as the enhancement of the northern regions of Nigeria's political relevance, and retrieval of power from the southern regions (Akinkuotu, 2000) may be regarded as a manipulation strategy for detonating religious riot time bombs and political crisis. Such monies might have equally made it possible for radical believers in some Nigerian states to be funded. A good example of such avenue is the 'Islam in Africa Organisation (IAO)' which has Nigerian statutes. According to the U.S. Department of State (2008), the IAO is being funded by some government organizations in Nigeria. Interestingly, the IAO is said to be an initiative of the OIC. Those actions also constitute a lack of respect for the secularism status of the state. The situation was further complicated by the lack of political will or constitutional courts to prosecute offenders who go against the law on secularism.

Despite the grievances or reactions generated from the singular foreign policy decision making by the Nigerian political leaderships, religion is becoming a mobilizing political force for people; it also works as an instrument for social, economic, and political change; as religious-based ideologies and movements seek political power through diverse methods. Religion remains an essential element in issues that govern international relations such as security, humanitarianism, intervention, human rights, terrorism, war and peace, and political movement.

Therefore, if religion is the beliefs, attitudes, emotions, and behaviors that constitute man's relationship with the power and principles of the universe and international relations are the strategies or the studies of power, state attitude, promotion of equilibrium, preservation of peace and prevention of war, then religion will continue to 
play a crucial role in international relations. One could argue that the future of the international system seems to be emanating from religious influences. Thus Nigeria, becoming a member of the OIC as orchestrated by General Ibrahim Babangida, was done based on his religious affiliation and interest in promoting the welfare of Nigeria's Muslim population and also to project the country for other socio-economic benefits. Apart from the global resurgence of religion, there is the global trend of the politicization of religion and the religionization of politics, which has subverted the traditional image of religion for being silent, negative, and depoliticized. It also has made fundamentalism (strong religion) and popular extremism interpretations of religion's role in international relations. The worldwide politicization of religion has various faces, such as the universality of religious extremism and fundamentalism, the "political awakening" of the religious organizations, and their large-scale involvement in politics. In the field of foreign policy, faith-based non-governmental organizations such as the OIC play an increasingly important role in the international political arena, the formation of global networks for religious advocacy, the international religious human rights mechanism, "the fourth wave of international terrorism," and the securitization of international religious issues.

\section{Summary}

In this chapter, the researcher theoretically and conceptually analyzed religion, international organization, and religious interaction in the state's international relations with other states and organizations in the global system, as in the case of Nigeria's membership in the OIC. When referring to religion, the study is not referring to the practices and beliefs of religion from a micro point of view, instead religion is the 
emblem or the symbol used to classify a community of people, in this case; Christians and Muslims.

Bourdieu's Theory of Habitus synchronizes views from both field participants and secondary information on the reasons for challenges and possible benefits of Nigeria's membership in the OIC. This enables the validation or invalidation of data collected from the two major sources, thus being able to reach a logical conclusion on the issue.

The field theory was used to analyze various viewpoints on religion's position in Nigeria's membership in the OIC. This theory ascertains whether the purpose of enrolling Nigeria into the OIC was to promote Muslim solidarity solely. This research is also quite unique in its approach. Though much literature is available on the topic of religion in Nigeria, and separately on the study and evaluation of the OIC, this research is one of the first to correlate the interaction between the two. This research is also one of the first to further develop how the interaction between these two subjects simultaneously affected the areas of religion, politics, economics, and capital in Nigeria. The next chapter, Chapter Three, will present a historical analysis of the emergence, activities, and functions of the OIC as a global entity. 


\section{CHAPTER THREE}

\section{THE ORGANIZATION OF ISLAMIC COOPERATION: EVOLUTION AND ACTIVITIES}

The idea of international organizations has probably been around since the advent of the ancient Greek City-States. From the writings of ancient Greek philosophers, hints of military alliances and international trading agreements are seen. Early Greek citystates of Athens, Sparta, and Macedonia once employed a common currency, which required a high degree of international cooperation. Most contemporary scholars point to the Congress of Vienna (18 15-1822) as the earliest modern precedent of today's IGO (Ihsanoglu, 2010). The Congress of Vienna, a multipurpose IGO, was created by the great European powers to re-established order and stability on the continent after the Napoleonic Wars. It was a forum for international collaboration on European security and commerce. It also strengthened the Rhine River Commission (1804), a bilateral IGO between France and the German confederation. This Commission established navigation rules for the Rhine River and an adjudication board to prosecute individuals accused of violating those rules. Similar river commissions were subsequently created for the Danube and Elbe rivers in Central and Eastern Europe.

The establishment of the OIC came as a result of the alleged Zionist arson attack against the Al-Aqsa Mosque on August 21, 1969, in "occupied Jerusalem," which constituted the last straw for Muslim countries that viewed themselves as being defeated. Even though a follower of the Jewish faith did not commit the attack, this incident gave rise to the formation of the OIC (Organization of Islamic Cooperation, 2016). The OIC is an Intergovernmental Organization with a strong religious element that regrouped fifty- 
seven Muslim or predominantly Muslim member states. Its priorities are promoting the interests of Muslim communities across the world, and fighting Islamophobia, especially in the western world (Weiss, 2015).

King Abdul-Aziz Bin Al-Saud opened the first World Islamic Conference at Mecca in 1926. Political issues such as territorial claims, safeguarding the holy places, improved conditions for pilgrims, and religious liberty for all Muslims Sects dominated the conference. The conference continued to hold throughout the 1930s and began to decline in the 1940s after the creation of the Arab League. In 1962 a division occurred when four different congresses were held. The division led to the forming of the Organization of Islamic Conference on September 22, 1969, held in Rabat, Morocco, with about Fifty-two countries in attendance. That number has since grown to fifty-seven (Weiss, 2015).

The OIC is based in Jeddah, Saudi Arabia, which indeed is its largest financial backer. Saudi Arabia constitutes its most influential state. It largely determines, along with a handful of other financial donors, what direction the OIC will take, which issues it will address, and the position it takes on those issues. Pakistan, Iran, and Turkey constitute some of the other powerful states within the OIC (Mayer, 2007). In January of 2014, Iyad Bin Amiii Madani, the former Saudi Minister of Culture and Information, became the OIC's new Secretary-General, replacing former Secretary-General, Ekmeleddin Ihsanoglu, from Turkey (Mayer, 2007).

The OIC was previously known as, the Organization of Islamic Conference, but changed its name in June of 2011, to The Organization of Islamic Cooperation," with the major aim of uniting and promoting Islamic solidarity (Weiss, 2015). Following the 
United Nations UN, the OIC is the second-largest international organization in the world. It is also the largest Islamic organization in the world, claiming to represent 1.5 billion Muslims around the world (Tadjdini, 2012). It is comprised of fifty-six UN Member States plus the Palestinian Authority. Some experts liken the OIC to the precursor of a future potential Islamic Caliphate (Tadjdini, 2012).

The OIC Member States vote together as a block in the UN, which affords them substantial power as the UN only has a total of one hundred and ninety three Member States. Indeed, the OIC has single rights on the UN Human Rights Council (HRC) and arguably constitutes the most influential power in the United Nations as a whole.

\section{The OIC's Charter}

The main objectives and commitments laid down in the Constitutional Charter of the Islamic Conference are to improve and strengthen Islamic friendship and solidarity among the Member States, protect and defend Islam's true image, prevent its deformation, promote dialogue among civilizations and religions, strive to achieve integrated and sustainable human development, and ensure the well-being of the Member States (Adam, 2015; Luis, 2001). The Charter also safeguards the right to selfdetermination and non-interference in the internal affairs of Member States as well as their sovereignty, independence, and territorial integrity.

The extent of the formerly mentioned goals led to the inclusion of certain priorities on its practical agenda, which has turned "the question of Palestine" into the center of attention at every Islamic conference, and a major topic of the SecretaryGeneral's pronouncements (Adam, 2015). At a meeting held in Conakry in 2013, the 
secretary-general called upon the Foreign Ministers to discuss the possibility of cutting ties or breaking off diplomatic relations with any state that recognized Jerusalem as the capital of Israel (Adam, 2015). Other issues addressed by the organization's agenda have been the countless conflicts its member states have suffered. Conflicts like the Soviet intervention in Afghanistan, which led to the Extraordinary Session of Foreign Ministers in Islamabad, January 1980), the Iran-Iraq conflict, the war in Bosnia-Herzegovina are examples of such issues (Othman, 2014).

Nevertheless, beyond its interventions in conflicts, the OIC contributes to its capacity as a subject of international law, to further institutionalize international society and develop its sources. The OIC, however, always maintains an Islamic perspective. Texts about human rights (Islamic statements discussed herein) or the adoption of covenants such as the Convention on Combating International Terrorism approved in 1999 have caused controversy (Organization of Islamic Cooperation, 2016).

\section{Characteristic/Features of the OIC}

There are three very interesting features of the organization are the OIC. The OIC is the sole existing organization based on an identifying religious conception as an element of unity among its member states, which Islam is the only common denominator and the only source of identity and integration. Article II (A) (1) of the OIC Charter stipulates that its prime objective is to "promote Islamic solidarity among the Member States" (Organization of Islamic Cooperation, 2016, p.3).

The OIC is not a regional body nor a universal organization. Its member states are from four different continents and only states that practice the Muslim faith can be 
granted membership. The OIC takes a political stance on the question of Palestine, consistent with the prevailing frame of mind that stemmed from the Cold War during the period the organization was established. Article VI (5) of the Charter indicates that OIC will have its headquarters in Jeddah (Saudi Arabia) until the liberation of Jerusalem.

The OIC covers a geographical area of great strategic importance from an international standpoint. An interesting detail in this connection is that the organization has no provisions regarding the "expulsion" of a member, as it only envisages the possibility of "suspension" or "provisional loss." Several member states, however, have been suspended since the birth of the OIC. Sierra Leone in 1974, Burkina Faso in 1980 and, recently, Syria are among those suspended states.

\section{Structure and Specialized Organs}

Regarding its internal structure, OIC consists of three bodies, two of them of a markedly interstate nature (Khan, 2001). The Conference of Kings and Heads of State and Government are known as the Islamic Summit Conference (Article IV of the Charter), the Islamic Conference of Foreign Ministers (Article V of the Charter), and the Secretary-General of the Organization. The former can be considered the supreme authority of the organization and its most important body since it lays down the strategies to fulfill the OIC's objectives.

Another body is an executive initiate in charge of implementing OIC's policy and adopting all resolutions and recommendations. Finally, the General Secretariat, located in Jeddah (Saudi Arabia), is elected by the Islamic Conference of Foreign Ministers and entrusted with the task of representing the organization at the international level. Throughout history, several Conferences have made significant contributions to OIC's 
development. Among others, those were held in Lahore (1974), Mecca (1981), Casablanca (1984), Kuwait (1987), and Dakar (1991). It should be noted that the OIC's Charter did not set up its judicial organ initially. It was not until the fifth Islamic Summit held in Kuwait in January 1987 that the Draft Statute of the International Islamic Court of Justice (IICJ) was conclusively approved (Lombardini, 2001).

Although the Court is yet to become active for lack of ratifications, its significance and originality cannot be denied (OIC, 2016). Regarding its composition and functions, Article 3(a) of its Statutes establishes that it shall be composed of seven judges, each elected to a four-year term and renewable only once. According to Article 4, these judges must be Muslim nationals of high moral standards, Shariah jurists of recognized competence, and experienced in international law. The jurisdiction of this organ, like other international courts, would be twofold: contentious and advisory, according to Articles 21 and 42 of the Statute. As to the sources of law, Article 27 states that the Islamic Shariah (Gomez, 2009) is the fundamental law of the court, and can only abide by general sources of international law (treaties, customs, general law principles, and international jurisprudence) as the second choice. This means that, for the first time in international law, a court would adopt the Shariah as applicable to solve international disputes.

Regarding the functioning of the court, interesting scenarios began to take shape in practice. Should two of its member's states decide to solve a border-related problem in this court, the judges would base their decisions on the sources of Islamic law: the Qur'an (the verbatim word of God) and the Sunnah (the revelation of God through the teachings and practices of the prophet Muhammad). Should they fail to find a principle that applies 
to the dispute, they would have to recourse to the secondary sources. The sources are the classic codes of international law. Interestingly, the statute does not refer to the judges to observe the school of religion (Maliki, Hanafi, shâfi‘ $i$, Hanbali), which could forebode legal difficulties (Gomez, 2009).

In addition to these domestic organs, OIC relies on several specialized bodies: IDB, ISESCO, ISBO, and IINA. The Islamic Development Bank (Gomez, 2009) (IDB) is the international finance guild for the entire OIC. While offering services such as equity participation, non-interest loans, and leased facilities, which contribute to the promotion of social and economic development within individual member states, and other Muslim communities throughout the world, the bank also supports technical cooperation between Islamic Countries. Similar to the Islamic Solidarity Fund (ISF), the bank provides relief to member states that suffer natural and human-made disasters.

The Islamic Educational, Scientific, and Cultural Organization (ISESCO) was formally established by the Eleventh Conference when resolution No. 2/11-C approved the statute of this newly created institution (Tadjdini, 2012). Its headquarters are in Rabat, Morocco. ISESCO aims to promote cooperation among member states in the fields of education, science, and culture. In the case of education, the organization recommends that Islamic ethics and values should be integrated into the syllabus. In the area of science, the use of modern technology and the development of applied sciences are encouraged within the framework of Islamic ideals, while cultural and educational exchanges are organized to promote world peace and security. This is achieved by encouraging cooperation between member states in the field of broadcasting vis-à-vis and 
the exchange of radio and television programs among the broadcasting organizations of these countries.

ISBO (Islamic State Broadcasting Organization) nurtures cooperation among OIC member states and also encourages them to come to terms with each other's religious and cultural heritage and social and economic progress (Tadjdini, 2012). It also encourages feelings of brotherhood among Muslims to unite them in the development of Islamic causes. More importantly, ISBO proclaims the principles of the Islamic Da'wah (preaching of Islam) and promotes the teaching of Arabic and other languages of its member states. The International Islamic News Agency (IINA) was formally established by the Third Islamic Conference (Jeddah, March 1972). Its main objective is to promote the exchange of information among news agencies about cooperation programs designed to enhance mutual understanding of political, economic, and social issues in member states. It also aims to upgrade the professional standards of the media in all member states based on Islamic values (Bergers, 2008).

\section{Functions of the Organization of Islamic Cooperation}

The OIC seeks to internationally outlaw, and ultimately criminalize all criticism of Sharia, Islam, Islamic theocracies, Muslims, and Islamic terrorism (Tadjdini, 2012). Though the OIC, contradictorily, claims that it supports freedom of speech, it also insists that freedom of speech does not include freedom to make blasphemous comments or "insults to Islam" (Hefner, 2011). Its support for the concept of combating defamation of religions serves to justify the harsh blasphemy laws that already exist in OIC countries like Sudan, Saudi Arabi, Iran, Pakistan, and Egypt. All predominantly Muslim countries have an Islamic blasphemy code, whether formal or informal (Zubedia, 2010). The 
defamation of religions campaign is targeted toward the West, as the OIC openly demands the implementation of Islamic blasphemy laws in Western countries; however, the effort isn't proving to be fruitful. The OIC continues to use multi-lateral conferences, consensus building, and legal instruments such as UN resolutions, and a more palatable language when dealing with free societies, in hopes of gradually achieving its goals.

The functions of the organization are listed in its 10-year action program adopted in 2005. The program envisages the joint activities of member states and promotes tolerance and moderation. The program hopes to pursue extensive reforms in all spheres of activities, including science and technology, education, and trade promotion (Tadjdini, 2012). The charter emphasizes good governance, the family values protected by Islam, and human rights in the Muslim world, concerning the rights of children, women, and the elderly (Tadjdini, 2012).

\section{Protecting Muslims and Resolving Conflicts}

The OIC has always attempted to resolve conflicts among its member states by peaceful means. During its early years, the OIC performed relatively well in this regard. This was noted when the OIC was an intermediary between the Palestine Liberation Organization (PLO) and Jordan (with the heads of state of Saudi Arabia and Egypt also playing a strong role) and between Bangladesh and Pakistan (with the OIC SecretaryGeneral playing a leading role) (Zubedia, 2010). These successes may be attributed to the capability and sincere leadership of the OIC.

Unfortunately, in the early 1980s, the organization failed to persuade Iran and Iraq to adhere to the proposals of the Islamic Peace Committee. Additionally, the OICs attempts to facilitate peace-making efforts in the southern Mindanao region between the 
government of the Republic of Philippines and the Moro National Liberation Front (MNLF) have not led to the implementation of the 1996 peace agreement. The OIC's efforts in this conflict have been channeled through its Peace Committee for Southern Philippines (OIC-PCSP), and the organization has offered a 16-million USD grant to the troubled region through the Islamic Development Bank (1DB) (Abdullahi, 2000).

The OICs promise in the field of conflict mediation in the Muslim world stems largely from its cultural competence and religious character. This proved an advantage in Somalia, where assistance from an Islamic organization was more acceptable to the Shabab Movement, allowing the OIC to 'open the way to other international donors (Khaled, 2005). The OIC may not impose its positions on the conflicting parties through force, but its moral influence has been effective.

In the case of the 2006 Mecca Declaration between Iraq's Sunni and Shia leaders, the OIC serves as a partner to the $\mathrm{UN}$ and other international organizations such as the European Union, the African Union, and the Arab League. The OIC can also play a complementary role by mediating between its member states or parties to a conflict existing within a member state. Currently, the OIC Secretary-General and his office do not have the necessary financial and human resources nor the political support of the member states to mobilize effective mediation missions on their own (Tadjdini, 2016).

\section{Interreligious and Intercultural Dialogue}

In its efforts to eradicate Islamophobia, the OIC has initiated a result-oriented dialogue with the West. The UN Human Rights Council adopted a resolution sponsored by the O1C on March 24, 2011 (Tadjdini, 2012). Resolution 16/18 on combating 
intolerance, negative stereotyping and stigmatization, discrimination, incitement to violence, and violence against persons based on religion or belief, condemns discriminatory practices against Muslims. Its adoption marked a defining moment for the OIC, which has searched for various novel ways to combat religious and ideological hatred. The OIC has hosted three follow-up meetings on the implementation of the resolution at an expert level (Mayer, 2005).

The OIC has gained recognition from Western states through these efforts, notably for a series of meetings known as the "Istanbul Process," a joint initiative related to the resolution as mentioned above launched in 2011 by US Secretary of State Hillary Clinton and OIC Secretary-General Ekmeleddin Ihsanoglu (Tadjdini, 2012; Tadjdini, 2016).

The OIC, as an international religious organization, has set the pace of the race to cope with the conflicts facing the Arab/Muslim world. The purpose of its evolution is often explained by pointing to the need for Muslim solidarity following two major events in recent history. The Arab loss of the Six-Day War in 1967 and the 1969 arson attack against the Al-Aqsa Mosque, a holy site in Sunni Islam. Its ability to mediate in various conflicts in the Arab world has been acknowledged by its member states as well as the international community. Its free-flowing relationship with the UN in their joint missions in Syria, and various actions undertaken by the OIC in collaboration with regional organizations such as the Arab League and the European Union, attest to its huge achievements in promoting world peace and the prosperity of its member-states. This has made the organization's voice to become significant around the world, so much that 
various international organizations, even non-Muslim states like Russia, have shown great interest to be granted OIC observer status.

\section{Summary}

In the previous section, the researcher presented the historical evolution of the OIC, its major structures, activities, and achievements. The next chapter, Chapter Four, is centered on Nigeria's membership in the OIC, its challenges, and its prospects. The chapter identifies the major benefits that Nigeria has aimed to gain from the OIC and negates the objective of Islamizing the country, contrary to some Christian opinion. 


\section{CHAPTER FOUR}

\section{NIGERIA'S MEMBERSHIP IN THE ORGANIZATION OF ISLAMIC COOPERATION: CHALLENGES AND BENEFITS}

In January of 1986, Nigeria joined the Organization of Islamic Cooperation (OIC)

(Abbas, 2018). Initially, Nigeria's status with the organization was that of an observer, but when General Ibrahim Babangida entered into political power as Nigeria's military head of state, the country became a fully enrolled member. This was done secretly and without the consultation of the Nigerians civilians (Lukur, 1999). This chapter provides data on the reasons, criticisms (challenges), and benefits of Nigeria's membership in the Organization of Islamic Cooperation.

\section{Rationale/Factors that Necessitated Nigeria's Membership in the OIC}

Nigeria is a densely populated country; however, it relatively has an equal representation of Muslims and Christians divided regionally. The North is predominantly Muslim, and the South is mostly Christian. The country is both a multi-ethnic and multireligious society, with Islam and Christianity being the dominant religions (Faseke, 2019). The northern part of the country had been Islamized several years before the advent of colonialism.

Consequently, after Nigeria's independence in 1960, there was a rise of Islam, and involvement with global Islamic organizations was a principal goal among the northern elites. The former government of the Northern Region created links with Islamic regimes, especially those in North Africa and the Middle East (Oded, 1987). It was because of this connection that Sir Ahmadu Bello, the late Sardauna of Sokoto, became 
one of those charged with "the responsibility of looking into the possibility of creating a permanent forum through which Islamic governments could interact frequently” (Olukoshi, 199, p. 493). The OIC was perceived as an institution that the Muslim segment of the country could readily identify with since the aim of the OIC is to unite Islamic nations both politically and economically (Luis \& Castillo, 2001).

After the burning of the al-Aqsa mosque and the assembly of Muslim leaders in Rabat in 1969, a delegation of Nigerian Muslims, led by Abubakar Mahmoud Gumi, attended the Rabat conference with the prodding of the Sultan of Sokoto, Abubakar III (Faseke, 2019). At the conference, Gumi pledged the support of the country's Muslim population towards the cause of solidarity. This was one of the acts which led to Nigeria's enrollment in the OIC a couple of years later (Olukoshi, 1990, p. 494). Once Nigeria became recognized as having an 'observer-status' within the organization, the status remained intact by successive governments for about fifteen years.

After the military's ouster of the civilian government of Alhaji Shehu Shagari on December 31, 1983, by Major-General Muhammadu Buhari, things took a slightly different turn. Powerful Muslim groups in the northern and southwestern parts of the country began vigorous effort to convert Nigeria into an active member of the OIC (ibid.). Some of these groups were commercial and industrial companies having strong business ties with the Middle East. These groups urged Buhari, who was already a devout Muslim, and could readily relate to the importance of Nigeria's conversion to become an active member (Ohadike, 1992). Many Arab governments also mounted pressure on the new government to yield to this request. They promised economic and financial assistance to the country should it become a full member of the organization (Faseke, 
2019). Such promises became particularly tempting during a stalemate in the country's $\$ 2$ billion loan negotiations with the International Monetary Fund (IMF). The stalemate also led to the blockage of lines of credit to the country by Western banks and the withdrawal of Western export credit guarantee agencies that handle the insurance coverage on exports destined for Nigeria (Olukoshi, 1990, p. 494). These conditions naturally caused inflation and economic hardship in the country.

Despite all the attraction of the pro-OIC lobbyists, Buhari still managed to exercise caution and sought the advice of the Ministry of External Affairs. He sent a memorandum to the Ministry of External Affairs requesting their take on the issue and their opinion of the advantages and disadvantages of joining the OIC. Ibrahim Gambari, the then Minister of External Affairs, in his reply to the memorandum, strongly counseled against the alteration of Nigeria's observer status in the OIC because of its secular posture, as provided in the 1979 constitution. He also noted that membership could create an issue that could lead to religious divisions in the country (Gambari, 1989). However, Buhari's response to this counsel did not reveal his stance. There were allegations from certain quarters that "Buhari had set in motion a process that would guarantee Nigeria's full membership in OIC and that his deputy, Tunde Idiagbon, had traveled to Saudi Arabia in mid-1985 to facilitate the logistics of this process" (Olukoshi, 1990, p. 494). The intentions of the Buhari administration concerning Nigeria's full membership in the OIC never materialized as he was ousted by Gen. Ibrahim Babangida coup on August 27, 1985.

The OIC matter did not end with Buhari's dismissal. Pro-OIC groups also pressured the new administration of General Babangida. Their argument remained ever 
persuasive in the face of incessant economic problems and the lack of assistance from Western financial institutions like the IMF. This warranted Nigeria, seeking potent alternatives to these Western financiers, to kick-starting the country's economic recovery. Much like his predecessor, General Babangida sought the advice of the Ministry of External Affairs on the implications of Nigeria's full membership in the organization (Faseke, 2019). The Minister of External Affairs at the time, Professor Bolaji Akinyemi, also counseled against such a move, citing similar reasons to those of Professor Gambari (Gambari, 1989).

In the interim, the OIC Secretariat in Jeddah sent an invitation to Nigeria in December 1985 to attend the organization's ministerial meeting that was taking place on January 6th - 10, 1986 in Fez, Morocco (Olukoshi, 1990). As was the practice, the Ministry of External Affairs asked the Nigerian Ambassador in Morocco to make arrangements to 'observe' the proceedings (Gambari, 1989). On January 1, 1986, Babangida also arranged a Nigerian delegation, made up of prominent Muslims, who held important offices in government, to attend the ministerial meeting in Fez (Abbas, 2018). The group was led by Rilwanu Lukman (the then Minister of Mines, Power, and Steel) and included Abubakar Alhaji (the then Permanent Secretary in the Ministry of National Planning), Abdukadir Ahmed (the then Governor of the Central Bank), Ibrahim Dasuki (the then Secretary-General of the Supreme Council for Islamic Affairs), and Abubakar Mahmoud Gumi, the former Grand Khadi of Northern Nigeria (Abbas, 2018). The delegation arrived in Fez on January 8th, and the next day, they participated in the meeting for the first time. Also, the Nigerian Ambassador to Morocco, who had been present from inception and had been oblivious of the impending arrival of the delegates, 
had registered his presence as an observer (Olukoshi, 1990). The Babangida's

administration, despite the warnings and the counsel from the ministry, decided to enroll Nigeria into the OIC as a full member (Faseke, 2019). It was during the first participation of the delegates at the meeting, on the 9 th of January, that Nigeria's formal application for full membership into the OIC was made (Babajimi, 2019).

The hierarchy of the organization was so profoundly delighted with this submission, that they decided to waive some procedures that were statutorily required for admittance into the OIC (Abbas, 2018). Rather than waiting a full probationary year before Nigeria's admission was communicated, the organizers of the meeting requested that its application be sponsored by existing members: a task that countries like Syria, Sierra Leone, Pakistan, and Senegal quickly fulfilled. When it was time for the conference chairperson to make his remark, he spoke in glowing terms of Nigeria and lauded the decision to convert from an observer to a full member of the association (Faseke, 2019).

\section{Major Challenges (Criticisms) of Nigeria's Membership in the OIC}

Following General Ibrahim Babangida's decision to enroll Nigeria into the OIC, criticism followed from various quarters, particularly from the Christians. This led to a national crisis as leaders from the two main religions responded predictably. While the Christian leaders called for an immediate withdrawal from the organization, Muslim leaders positively hailed its continuation. Prominent clerics such as Archbishop Okogie of Lagos, Peter Y. Jatau, the Catholic Archbishop of Kaduna, Professor Aluko, the renown Nigerian economist, Tanko Yusuf, as well as the news media, all publicly reminded the government of the unconstitutionality of the decision taken, based on the 
'secular' status of the country (Kukah, 1993). However, these appeals fell on deaf ears. Several Church groups also reacted to the country's OIC membership and requested immediate withdrawal. According to Falola:

"The Catholic bishops felt the OIC issue had soured the relations between Muslims and Christians in Nigeria, making it difficult to build a united country based on equity social justice, and respect for human rights regardless of religion. The bishops were disappointed that the government had even admitted to OIC membership without acknowledging that it should have consulted the public before joining. They affirmed without any ambiguity that 'we do not and shall not agree to Nigeria's membership of the OIC.' It dismissed all the government's justification as unconvincing (Falola, 1998).

The Christians within the polity used the country's secularity, based on the 1979 constitution, as an excuse to distance the country affiliating with institutions perceived to be exclusively for Muslims. Many questioned if a multi-religious society should be involved in an organization that is steeply rooted in and governed by Islamic beliefs. Muslims anchored their support on the interpretation of the secular status of the country, arguing that the secular posture of the country had not been violated in any respect since the country was not adopting Islam as a state religion. This partially explains the controversy that arose from Nigeria's admission to the OIC.

Championing the Christian opposition was the Christian Association of Nigeria (CAN), which was led by Archbishop Okojie (Olukoshi, 1990; Bankole, 2019). Its position was for Nigeria's total and unconditional withdrawal from the OIC. According to Okojie, "if it were a section of the Islamic Community that joined, there is no problem, but for Nigeria as a country, we hold the President responsible for this. The resident alone does not makeup Nigeria" (Okojie, 1986, pp. 12-14). In response, the umbrella body of 
the Muslim community, Jama'atu Nasir Islam (JNI), argued that the call for withdrawal was part of the 'insensitivity of Christians towards matters that concern Muslims. They proposed that should Nigeria withdraw from the OIC; it would also have to withdraw diplomatic relations with the Vatican' (Jama'atu Nasir Islam, 1986).

Other debaters who were not as extreme in their views as the CAN tried to defend their positions in more concrete terms. For example, those that favored Nigeria's association with the OIC argued that Christians had exaggerated the negative implications of the OIC, pointing out that some Christian heads of state like Uganda, Rwanda, Gabon, Kenya, Cameroun, Sierra Leone, and the Benin Republic were members of the OIC; and therefore, the organization was not essentially a religious one, but instead, it is structured similarly to the makeup of the United Nations (Lawal, 2018). This group of people also emphasized the positive financial implications like monetary and technical assistance as well as the low-interest loans, which the Islamic Development Bank (IDB) provided.

The two opposing sides' failure to relent led to a period of tension and religious crisis in the country. According to Falola (1998), "in every way, Nigeria's entry into the OIC turned out to be a costly miscalculation. The resulting controversy polarized the country along the religious divide more than had any other issue in Nigerian history" (p.95). The chaos inflicted on the nation as a result of this action cannot be underestimated. A lot of religious riots were witnessed, especially in the North between Christians and Muslims. At no time were Christians observed as reacting so vehemently as during this period (Lukur, 1999). Lectures, seminars, and even books were written in 
the plea of the government retracting their decision. Despite the outcry that the OIC fuss generated from certain quarters, the fact remains that in 1986 Nigeria became, and remains, the 46th member of the OIC (Faseke, 2019).

One important lesson learned from this is, the potency of public opinion in foreign policy conduct, ultimately, foreign policy decision-making in Nigeria, lies in the hands of two institutions: The Ministry of Foreign Affairs (then External Affairs) and the Commander-in-Chief. In the case of Nigeria's membership in the OICs, the latter has had an ultimate say and, therefore, opts to isolate the former in implementing its preferred courses of action.

\section{Nigeria's Membership in the Organization of Islamic Cooperation: Critical Analysis}

The enrollment of Nigeria into the OIC created a bone of contention among Nigerians as to whether the decision was intended to Islamize the country. There are many arguments and counter arguments to this effect. Apart from the numerous secondary or written sources that are reviewed on the reasons or motivations for Nigeria's membership in the OIC, the researcher also presents the views of some scholars in the field of International Studies and Political Science, as a source of oral evidence to confirm the reviewed subject matters secondary information.

While in Nigeria during the researcher's undergraduate program, a discussion on the subject of "why states behave the way they do in the international system" was held between the researcher and one of his lecturers, Professor Eddy Erhagbe, of the Department of International Studies and Diplomacy, Faculty of Arts, University of Benin, Benin City, Nigeria. When the researcher asked the question: "Why Nigeria enrolled in 
the OIC by the governmental leadership of General Ibrahim Babangida, and whether it

was to Islamize the country?" Prof. Eddy Erhagbe asserted:

The decision taken by the government was a foreign policy decision taken to serve not only the interest of the Muslim population in the state but also for economic reasons. Therefore, we cannot state categorically that the government of Nigeria had the intention of Islamizing the country with the enrolment of Nigeria into the OIC. When a state decides to enter into a league or to join an international body, a major motive is to secure economic gains.i

This view was corroborated by a Professor of International Organization,

Professor M.I.M. Abutudu, of the Department of Political Science, in the same

institution, during a departmental seminar on the topic: "Nigeria's Membership of

International Organizations: To What Ends?" Prof. Abutudu noted that:

The government of a state has the authority and capability to make decisions on behalf of its citizens on the nature and pattern of its international relations in the global system. The major concern of the government is to ensure that its national interests are pursued towards ensuring the peace and development of the state.ii

Moreover, a Professor in the Department of International Studies and Diplomacy,

Professoor Leo Otoide, during a lecture on "Nigeria's Foreign Policy," once noted that:

The fundamental issue in the foreign policy of sovereign states is the pursuance of their national interest. There are three central elements in the national interest of the Nigerian state, and they are socio-economic selfreliance, peace/security, and respect among the comity of nations.iii

In another development, a scholar from the Department of History, from the same

institution, Prof. O.B. Osadolor noted that:

A major issue in Nigeria today is the wrongful application of religious beliefs. We tend to bring religious bias into almost everything. Thus, religious sentiment has almost divided us. Most of the security issues in the country today were triggered by religious sentiments.iv 
From the preceding oral evidence, the researcher's question of whether Nigeria was enrolled in the OIC to Islamize the country resulted that Nigeria did not enroll for such reasons and that freedom of religious worship in Nigeria will not be interrupted or altered by this decision. Additionally, it's been over three decades since Nigeria became a member of the OIC, yet, no attempts have been made by the successive governments to implement or enforce nationwide Islamic practices. A country's decision to join any international organization is a foreign policy issue and should, therefore, be perceived from the lens of international politics (Gamawa, 2019). Section 19 of the 1999 constitution outlines Nigeria foreign policy objectives to include:

promotion and protection of national interest; promotion of African integration and support for African unity; promotion of international cooperation for the consolidation of peace and mutual respect among all nations; eliminating discrimination in all its manifestations; respect for international law and treaty obligations as well as the seeking of settlement of international disputes by negotiation, mediation, conciliation, arbitration, and adjudication as well as the promotion of just world economic order (Nigeria 1999 Constitution, 1999, p.734).

The goal of any policy framework is the ultimate objective to be realized (Opara, 1986). Therefore, Nigeria's concern regarding foreign policy is the nation's sustainability and the wellbeing of its citizens. In Nigeria's foreign, economic, and defense policy, the principal goal of its national protection laws is the security and wellbeing of the state, its citizens, and its resources (Opara, 1986). Protection refers to its responsibility and obligation to every citizen and making sure that the country's assets are guarded. The depth of this principle requires deliberate effort to defend and protect the territory, resources, government, citizens, and their property, regardless of their location and circumstances. The overall synopsis of this principle is to defend Nigeria at all costs. This 
principle of national protection is fundamental is always considered in Nigeria's decision making in foreign relations (Gamawa, 2019).

The promotion of national interest includes Nigeria's achievement of the needs, desires, and expectations of the government. This can be achieved through membership in an organization or a bilateral trade agreement, etc. The promotion of national interest is not restricted to government projects; it can extend abroad to private businesses, student's welfare, and pilgrim's welfare in other countries like Saudi Arabia or Israel. Nigeria being such a diverse country with a huge population means the government has a greater commitment to creating the right environment and atmosphere for the continued existence of the land, the people, and their growth. (Gamawa, 2019; Obioma, 1986).

Apart from the desired economic gains, the fact that almost half of Nigeria's population is Muslim was a major motivation for Nigeria's involvement in the OIC. Having an international organization that coordinates the activities of Muslims across the globe, including activities that concern pilgrim's regulations in Saudi Arabia, it was reasonable that Nigeria should seek membership. Membership in the OIC assists in protecting almost $50 \%$ of the country's civilians. The supporting evidence and the understanding of the laws confirm that this decision was to protect its citizens and promote the national interest.

\section{Benefits of Nigeria's Membership in the Organization of Islamic Cooperation}

The main argument of this research is that Nigeria's membership in the Organization of Islamic Cooperation was primarily for economic benefits. In this section, the study assesses some of the numerous economic benefits which Nigeria has accrued as a result of its membership in the OIC. 
Since its inception, the organization has had tangible economic impacts on some of its member states. This has been demonstrated through its affiliated institutions like the Islamic Development Bank (IDB), Islamic Educational Scientific and Cultural Organisation (ISESCO), and the Standing Committee for Economic and Financial Cooperation (COMCEC), among others (Gamawa, 2019). Indeed, one of the earliest notable examples of the OIC's influence is the raising of $\$ 10,000,000$ among members in 1988 to help Palestinians who were 'victims of Israeli oppression in the occupied West Bank and Gaza areas (Al-Gabid, 1993). Also, towards the end of 1989, the OIC set up a 'food reserve scheme,' which was to help member countries cope with emergency food shortages. Each participating nation would pledge one percent of its consumption of staple food to the OIC reserve to be kept in the country ready to be shipped out at any time it was needed by another member. Another example is Saudi Arabia assisting in canceling the official debt owed by less developed countries (LDCs) that were members of the OIC.

One of the most beneficial affiliated organizations is the Islamic Development Bank (IDB), which is a subsidiary institution of the OIC. Apart from the millions spent in Africa during the 1990s, the "IDB Cooperation Framework with Africa" initiative, was also funded with a commitment of $\$ 2$ billion for least-developed member countries in Africa. The initiative would last over five years (2003-2007) (COMCEC, 2017). This was extended through Special Programs for the Development of Africa (SPDA), which was a $\$ 12$ billion investment program in African countries during 2008-2013 (COMCEC, 2017). 
Having endorsed Nigeria's membership of the OIC, President Olusegun Obasanjo effectively enrolled Nigeria into the IDB in 2005 with the purchase of 0.03 percent of the overall capital of the bank (Ezeanokwasa, 2007). This capital subscription was increased to 7.69 percent in June 2010, making the country become one of the nine permanent members of the Board of Executive Directors (ibid.). This also made Nigeria the fourthlargest equity subscriber to the IDB with 1,384 million Islamic dinars (ID). In reward for such commitment, Nigeria has been able to attract quite a hefty amount of economic benefits.

In pursuance of the Nigerians government's implementation of transformation and IDB's Strategic Plan, an indicative 3-year Country Programming Framework (20122015) was formulated. Under the program, the bank and its affiliates provided financing envelop of $\$ 2$ billion for the implementation of projects prioritizing agriculture, energy, transportation, water supply and sanitation, education, and health. In fact, as of 2012 alone, the bank considered a budget of about $\$ 700$ million solely for Nigeria. This included eight approved projects of about \$200 million and trade financing for \$205 million granted to prominent companies and banks in the country (Gamawa, 2019). This is separate from the $\$ 30$ million for the 'Food Security Program' that covered Gombe and Yobe States. Also, provision was funded for the construction of four Model Science Secondary schools and 300-bed hospitals in Kaduna State. Integrated Rural Development Projects and Bilingual Education Programs were also provided in at least 11 other states (Faseke, 2019). In April 2012, under the 'Reverse Linkage Program,' the IDB also sponsored study visits for 13 Nigerian irrigation experts from seven states and Federal Ministries of Agriculture and Water Resources. The visits lasted for two weeks, and the 
goal was to successfully implement/manage small-scale irrigation projects in Indonesia (Faseke, 2019). The overall vision of the visits was to enable the delegation to observe best practices, provide short term training institutions for operators, and provide maintenance for Nigeria's small-scale irrigation infrastructures. The visits also provided small scale farmers insight on how to improve their agricultural productivity and reduce their dependence on rain-fed agriculture.

Another significant event that occurred in 2012 was the establishment of a Group Gateway Office in Nigeria to foster cooperation and enhance the bank's presence in the country and improve its client responsiveness (Gamawa, 2019). States desirous of IDB financing for projects in the category of Medium-Term Priorities were to apply through the IDB Governor assigned to Nigeria (also statutorily Nigeria's Minister of State for Finance) along with a detailed feasibility study and the State's Assembly Resolution authorization. In a case where the feasibility was not available, the bank could instead consider financing it upon the request of the country. Private sector applications for financial support were also accommodated through this medium, requiring only a direct application (accompanied with a comprehensive project report) to the IDB Governor. Adamawa, Gombe, Kaduna, Kano, Kwara, Nasarawa, Niger, Osun, and Yobe are states that have benefited from these interest-free loans (Faseke, 2019). Most southern governors are yet to enjoy such benefits, and this may be not to offend the significant Christian population in their constituencies.

In January 2016, the IDB came up with the "Bilingual Education Scheme." The program educates jobless youths with both Islamic and Western education (Faseke, 2013). This is significant because the bulk of these idle youths constitute the target 
recruitment pool of the Boko Haram (BH) (Faseke, 2013). This was done in a bid to reconstruct northern Nigeria after the $\mathrm{BH}$ onslaught had ravaged the region between 2009 and 2016. This arrangement was made on January 31, 2016, when the IDB's President, Ahmad Ali, received a high-level delegation of five governors from the Northern Nigerian States Governors Forum (NSGF). The delegation was led by the Governor of Borno State, Kashim Shettima, and included Abdullahi Ganduje of Kano State, Nasir ElRufa'i of Kaduna State, Umar Al-Makura of Nassarawa State and Muhammad Abubakar of Jigawa State. Ali committed himself and the IDB to "working together to come up with a comprehensive and constructive plan to support northern Nigeria" (Tukur, 2016). According to him, "We will start with education, particularly bilingual education, and other areas such as job creation" (Tukur, 2016). In the weeks following that initiative, the IDB provided \$98 million for the Bilingual Education Programs in Adamawa, Gombe, Kaduna, Kano, Kwara, Nasarawa, Niger, Osun, and Yobe, and also promised to support similar projects in other states of the country (Adetayo, 2016).

This development was welcomed by President Muhammadu Buhari, who, a few weeks later, also welcomed an offer by the IDB to organize a financing round-table in Abuja to mobilize more funds for investment and the development of infrastructure in Nigeria.

Nigeria's immediate neighbors are all members of the OIC, and two of them, Benin and Cameroon, have Christian presidents and are predominantly non-Muslim populations (Faseke, 2013). Contrary to the statements of those opposing Nigeria's involvement in the OIC, it is unlikely that these countries, along with many other countries having a large Christian population, would be part of an organization whose 
agenda was to Islamize their citizens. The fifty-seven member states of the OIC are also members of the United Nations, with Nigeria maintaining bilateral relations with some of them. Since their bilateral relations do not substitute their joint membership in the United Nations or other regional organizations, such as ECOWAS or The AU, it goes without saying that multi-layer affiliation is a norm in international relations. This demonstrates that each regional or global grouping has exclusive areas of focus common to all its members.

Egyptian-made buses are used in Nigeria (Gamawa, 2019). The multi-million dollar investment going into the Malaysia Gardens projects in Abuja and the $\$ 400$ million investment brought to our telecom industry from the United Arab Emirates are also some of the benefits derived from Nigeria's membership in the Organization of Islamic Cooperation (Tukur, 2016). Therefore, evidence proves that there have indeed been developmental gains from Nigeria's involvement with the OIC through its separate agencies. For example, the fear that Nigeria will expend more money on the organization than it would reap the rewards has proved to be unfounded. As a member, nations pay the same amount of annual subscription and are free to take advantage of the full benefits being supplied to them (Shinkaiye, 2018). Akinyemi agreed that there were economic gains from the organization; however, he also cautioned that 'one has to keep in mind that at times economic gains may not be sufficient to counter strategic problems that you get yourself into by certain decisions' (Akinyemi, 2018). He also opined that, though there are Christian countries in the OIC, these countries do not have the same level of religious tensions that already existed in Nigeria. 
Recently, during the 2019 OIC Summit held in Makka, Saudi Arabia, to mark the 50th anniversary of the OIC, President Muhammadu Buhari and other heads of state, represented their countries. The issues of concern at the Summit included: safety, peace, and prosperity of member-states and their citizens. It is noteworthy that during the meeting, President Buhari got key support from other African leaders for many issues about Nigeria and the entire African continent. Top on the list was a strong condemnation of terrorist acts (Agency Reports, 2019). The meeting agreed that fighting terrorism is a major priority and resolving to work together to "prevent and suppress terrorist acts through strong international solidarity and cooperation in full recognition of the UN's central role in that regard" (Agency Report, 2019). President Buhari also received reassuring support for the recharging of the Chad Basin, a goal he has consistently promoted. The Lake shrunk to 10 percent of its size due to the effects of climate change and had dire economic consequences. The OIC members assured their support for the ongoing project of recharging the Lake, because of the socio-economic benefits it would bring to neighboring countries (Agbakwuru, 2019). Reducing poverty and hunger was also discussed extensively. Members saw the need and made strong commitments to assisting less privileged member-countries to tackle poverty and hunger. In line with this, The Islamic Organisation for Food Security was charged to address the challenges of agriculture, rural development, and food insecurity. The robust, meeting, touched economic and social issues affecting members, relying on the strength of collective efforts to find immediate and lasting solutions. The meeting agreed to aid the fight to end terrorism; support members that are behind in economy and development; empowerment 
of youths through knowledge and entrepreneurship, and advance causes relating to women (Agbakwuru, 2019).

Other significant gains include the agreed-upon goal to discourage marriage of underage girls corporately; increase trade and investment; promote science, technology, and innovation, promoting culture, financial development, preserve the marriage institution, arrest climate change, sustain advocacy on the issue of Palestine, and working together for peace, security and co-existence. Irrespective of its status as being an organization that emerged from Muslim solidarity, the OIC transcends faith to provide economic and political opportunities for member nations (Luis \& Castillo, 2001). 


\section{CHAPTER FIVE}

\section{CONCLUSION}

This study examined Nigeria's membership in the Organization of Islamic Cooperation (OIC). The study's intentions and objectives were clearly stated in the background section: (1) to examine the historical development of the OIC; (2) to analyze the role of the OIC; (3) to examine the nature of Nigeria's membership in the OIC, and (4) to evaluate the challenges and benefits of Nigeria's membership in the OIC.

During the study, the second chapter provided a theoretical literature review on the concepts of religion and international organizations because the OIC is both a religious and international organization. The study also reviewed the historical origin, nature, and major achievements of the OIC. The study examined the rationale and factors that necessitated Nigeria's membership in the OIC, the criticisms, and counter criticisms (major reactions) that greeted the decision. Finally, the study reviewed the numerous economic benefits that Nigeria has reaped as a member of the OIC. This factor is the basic argument and the focal point of this study. The study also revealed that in the theory of field, when two or more fields interact, at some point, one of the fields dominates or overpowers the rest. The fear of the religious field becoming dominant is what triggered the Christians in Nigeria to protest membership in the OIC. Through the theory of habitus, the study reveals why Christians in Nigeria, through their individual experiences and beliefs, were fearful that an Islamic takeover that would strip Nigeria of its secular freedom, and cause Christians to change their way of life. 


\section{CONCLUSIONS}

This issue highlights the place of religion in international relations, particularly in a multi-ethnic and multi-religious country like Nigeria. Indeed, Nigeria's membership in the organization is just one of several issues that have caused cleavages between Christians and Muslims in the country. Perhaps, what makes this case more sensitive is the secrecy associated with its membership. This appears to have brewed suspicions and speculations, particularly among the Christian segment of the population.

However, the religious sensitivity in the OIC issue in many ways made people rethink the lack of openness in the country's foreign policy. Apart from the fact that openness could have prevented the heated passion with which the matter was received, Nigeria perhaps would have by now evaluated the cost and benefits of membership or non-membership more objectively and effectively.

Looking at Nigeria's membership in the OIC within the context of the country's secular posture, it is clear that the 1979 and 1999 constitutions brand Nigeria a secular nation, but what that exactly means is subject to interpretation. If, as we have identified, there are material gains in being members of the organization, then such membership should be embraced, and the nation should seize every opportunity membership provides. Although, it is not an easy task to convince critics that Nigeria's OIC membership is not a constitutional breach and that instead, it is a mere issue that has to do with foreign policy and its objectives that were outlined in the constitution and itemized alphabetically (i.e., a-e). The membership assists with the concern of what happens to Nigeria's Muslim citizens outside of Nigeria, and policies are shaping the activities of Muslims around the 
world and in different countries. Nigeria's foreign policy is not concerned with tribe nor religion; it is, however, concerned with citizens, what they do, and what will affect them outside of the Nigerian territory.

Finally, it has been the contention of this study that the OIC matter is not focused on religion; that is, the international solidarity for Muslim's religious interests, but more about assessing the huge economic benefits that accrue to member states, of which Nigeria has enjoyed. Therefore, Nigerians and critics of the OIC membership need to objectively evaluate the need for Nigeria's involvement with the OIC in terms of the economic benefits the country gets from it. The economic benefits from the OIC membership include assistance from the Islamic Development Bank based in Jeddah, Saudi Arabia, or the Islamic Education, Scientific, and Cultural Organization, and the Lake Chad Basin projects.

\section{Recommendations}

Given the above conclusions, the study makes the following recommendations:

There is a need for a re-orientation on the of the critics against Nigeria's membership in the OIC, to objectively evaluate both the religious and socio-economic ideologies of the OIC in order to benefit grasp the rationale behind Nigeria's involvement in the organization. Nigeria's membership in the OIC should be viewed from the perspective of international relations with economic interest as its basis.

The government of Nigeria should endeavor to be open and transparent in its local and foreign policy implementation, especially as it concerns major issues like the OIC to avoid chaos and division among the multi-ethnic and multi-religious citizenry. In line with this, there is a need for the government and its policymakers to educate the public on 
the nature and benefits of such policy implementation before taking steps to execute such policies or programs.

Any activity that concerns Nigerians should be of paramount importance to the Nigerian Government, especially if the promotion of national interest and the principle of national protection as enshrined in the foreign policy objectives is to be followed and is understood. This is to ensure the protection of its citizens and promote the national interest.

\section{Bibliography}

Adam, A. 2015. Understanding the Role of the Organization of Islamic Cooperation in Human Rights. Copenhagen: The Danish Institute for Human Rights.

Akeel, M. 2012. “OIC Human Rights Body Identifies Women's Rights, Education, Development and Research as Priority," OIC Journal, 20 (4): 28-30.

Al-Gabid, H. 1993. "The Organization of Islamic Conference (OIC) and the Development of Africa." In Nura, A., Adamu, A., Awwal, Y., Rashid, M. Haruna, S. (Eds.), Islam in Africa: Proceedings of the Islam in Africa Conference. Ibadan: Spectrum Books; St. Helier and the Channel Islands: Safari Books, pp. 305-21.

Adam, A, 2015. Understanding the Role of the Organisation of Islamic Cooperation in Human Rights Copenhagen: The Danish Institute for Human Rights, pp.34-35.

An-Naim, A.A. 2000. Islam and the Secular State. Cambridge, MA: University Press, p.196.

Akinkuotu, A. 2000. "Defusing the Sharia Bomb," TELL, No.16, April 17: 12-16.

Archer, C. 1992. International Organization, 2nd Edition, London: Routledge, p. 4.

Armstrong, D. Lorna L. and John R. 2004. International Organisation in World Politics.3d ed. Basingstoke, UK: Palgrave Macmillan, p.12. 
Art, R. \& Robert, J. 1996. International Politics: Enduring Concepts and Contemporary Issues. New York: Harper Collins.

Beckford, J. 2003. Religion: A social constructionist approach. In Social Theory and Religion Cambridge: Cambridge University Press, pp. 11-29.

Bergers, M. 2008. Islamic Views on International Law, The Hague: The Hague Academic Press, pp. 105-117.

Bourdieu, P. 1990. The Logic of Practice, Cambridge: Polity Press. . 1980. The Logic of Practice. Stanford, Stanford University Press.

Bruce, S. 2003. Politics and Religion. Cambridge: Polity Press pp. 14-62.

Deutsch, K.W. 1978. The Analysis of International Relations, Englewood Cliffs, New Jersey: Prentice Hall Inc, p. 100.

Duverger, M. 1972. The Study of Politics, London: Nelson, p. 68.

El Fadi, K.A. 2005. The Great Theft: Wrestling Islam from the Extremists, New York: Harper Collins, pp.123-124.

Falola, T. 1998. Violence in Nigeria: The Crisis of Religious Politics and Secular Ideologies. New York: University of Rochester Press.

Gilbert, A. D. 1980. The making of post-Christian Britain. London: Longman.

Hassan, W. 2015. "The Role and contribution of OIC in the development of educational and scientific facilities in the Muslim world." Journal of Political Studies, 22 (2): p. 90-94.

Haralambos M., Holborn M. and Heald R. 2008. Sociology themes and perspectives (7th edition), Harper Collins Publishers Limited London.

Hughes, B. 1994. Continuity and Change in World Politics, 2nd Edition, Englewood, Cliffs, NJ: Prentice-Hall, p. 260.

Hefner, R.W. 2011. "Introduction," in Shari 'a Politics: Islamic Law and Society in the Modern World, (ed.), Robert W. Hefner (Bloomington: Indiana University Press, p. 2123.

Ihsanoglu, E. 2010, The Islamic World in the New Century: The Organization of Islamic Conference, 1969-2009. New York: Columbia University

Press. 2010. 
Iarzan, S. 1992. Islam and Islamic Groups. London: Longman.

Jama'atu, N.I. 1986. "The Position of Muslims with Regard to OIC Press Statement." New Nigeria, March 20.

Jones, S. 1997. The Archaeology of Ethnicity: Constructing Identities in the Past and Present. London and New York., Routledge Press.

Kayaoglu, T. 2013. The Organization of Islamic Cooperation's Evolving Human Rights Framework. Washington, D.C.: The Brookings Institution.

Kukah, M.U. 1993. Religion, Politics, and Power in Northern Nigeria. Ibadan: Spectrum.

Kukah, M.F.I. \& Falola, T. 1996. Religious Militancy and Self-Assertion: Islam and Politics in Nigeria. Hants: Avebury.

Khan, S. 2001. Reasserting International Islam: A Focus on the Organization of Islamic Conference and Other Islamic Institution. Oxford: Oxford University Press, 2001.

Khaled, M. 2007. Globalization and Religion Conference on Globalization, Conflict \& the Experience of Localities Rome, Italy 28-29 June.

Luis, V. \& Castillo, Gutierrez 2001. The Organization of Islamic Cooperation in Contemporary International Society. Oxford: Oxford University Press.

Lukur, M. 1999. Leadership and Governance in Nigeria. London: Hodder Arnold.

Lombardini, M. 2001. "The International Islamic Court of Justice: Towards An International Islamic Legal System?” Leiden Journal of International Law,Vol.14, pp. 665-680, September.

Mayer, A.E. (2007). Islam and Human Rights, Boulder C.O: West-View Press, p.77.

McCullough M. and Willoughby B. (2009). Religion, Self-Regulation, and Self Control. Associations, Explanations, and Implications Psychological Bulletin Vol. 135, No. 1, 69-93.

Moncrieffe, J. 2006. “The Power of Stigma: Encounters with 'Street Children' and Restavecs' in Haiti." IDS Bulletin, 37(6): 31-46.

Nwanaju, I. U. 2005. Christian-Muslim Relations in Nigeria. London: Longman. 
Obilor, J.I. 2002. Religion as the Bedrock of Any Democracy: A Key to Nigerian Survival. Journal of Nigerian Languages and Culture. Vol. 3, June.P.63.

Odumuyiwa, E. A. 2006. Religion and child development. In Orisun: Journal of Religion and Human values. Ed. K. A. Balogun: pp. 1-15. Vol. 4 \&5, 2005 2006.

Olukoshi, A. 2000. "Globalization, Equity, and Development: Some Reflections on theAfrican Experience," Ibadan Journal of Social Science, Vol. 2, No.1, September, pp. 23-42.

Omoregbe, J. 1993. A Philosophical look at Religion. Lagos: Joja Educational Research and Publishers Ltd.

Organization of Islamic Cooperation, 2016. The Custodian of the Two Holy Mosques chairs the 14th ordinary Islamic Summit, p. 2.

Othman, J. 2014. "Towards OIC Economic Cooperation: Impacts of Developing A Preferential Trade Agreement." UNESCO Forum on Higher Education, Research Knowledge, 20 (4): 109-112.

Palmer and Perkins, H.C. 1954. London: Stevens \& Sons p.299

Pearson, F.S. \& Rochester, J.M. 1984. International Relations: The Global Condition in the Late Twentieth Centur. Reading MA, Wesley: Addison, p. 322.

Ray, J.L. 1992. Global Politics, 5th Edition, Boston: Houghton, p. 425.

Spiro M. 1966. Religion: Problems of definition and explanation. In Banton M, editor. Anthropological approaches to the study of religion. London: Tavistock; 1966. pp. 96-97

Swartz, D. 1997. Culture and Power: The sociology of Pierre Bourdieu. Chicago, University of Chicago

Toft, M.D. 2010. "God's Century: Resurgent Religion and Global Politics," The Huffington Post, March 10.

Tadjdini, A. 2012. "The Organization of Islamic Cooperation and Regional to International Law and Security," Amsterdam Law Forum, 4(2), pp.3637. 
Tadjdini, A. 2016. "The OIC and Regional Challenges to International Law and Security" and International Ethical and Humanist Union, "Universality is Under Attack at the UN," retrieved on www.iheu.org/node/2874. 12/06/2019.

U.S. Department of State Diplomacy in Action (2008). International religious freedom report 2008 www.state.gov./j/drl/rls/irf/2008/108385.htm accessed on 13 November 2014.

Usman, B. 1987. The manipulation of religion in Nigeria 1977-1987. Kaduna: Vanguard Publishers.

Wacquant, L. 2005. Habitus. International Encyclopedia of Economic Sociology. J. Becket and Z. Milan. London, Routledge.

Wendt, A. 1999. Social Theory of International Politics, New York: Cambridge University Press.

Weiss, D. 2015. The Organization of Islamic Cooperations Jihad on Free Speech, North Charleston: Create Space Independent Publishing, pp.45-46.

Zubedia, S. (2010). Law and Power in the Islamic World (New York: I.B Tauris,p.45.

i Eddy Erhagbe is a Professor of International Studies, Department of History and International Studies, University of Benin, Benin City, Nigeria.

ii M.I.M. Abutudu is a Professor of Political Science (with specialization in International Organization), Department of Political Science, University of Benin, Benin City.

iii Leo Otoide is a Professor of International Studies, Department of History and International Studies, University of Benin, Benin City, Nigeria.

iv O.B. Osadolor is a Professor of History, Department of History and International Studies, University of Benin, Benin City, Nigeria. 